\title{
The effect of industry type on long-run performance of initial public offerings for privatized companies in the Iran
}

\author{
Saeed Nouri Hoseinabadi* and Alaleh Yazdani
}

Department of Accounting, Zavareh Branch, Islamic Azad University, Zavareh, Iran

\section{H R O N I C L E \\ A B S T R A C T}

Article history:

Received October 15, 2012

Received in revised format

4 December 2012

Accepted 8 December 2012

Available online

December 102012

Keywords:

Privatization

Initial public offerings (IPOs)

Buy-and-hold abnormal return

Stock return

Industry type

\begin{abstract}
In the current study, the effect of industry type on the long-run performance of stock pricing in the initial public offerings (IPOs) of privatized state-owned companies (SOEs) in Tehran Stock Exchange is studied. The proposed study applies long-run buy and hold return index of the stock. The sample population of the study includes the privatized SOEs present in TSE over the period 2001- 2006. The assessments of this study shows that long-run stock buy- and- hold return of the companies admitted in stock exchange is less than market's long-run return during the same period after 36 months and the industry type has impacted on long-run buy- and- hold return of the admitted companies.
\end{abstract}

\section{Introduction}

Two recent decades have been the golden era of financial capitalism and there are different evidences for such changes such as intellectual capitalism and economic power. In fact, during the past few decades, there has been rapid growth in total value and trading volume of capital market in the world's financial markets such as stocks and commodity markets and there have been a tremendous development of privatization in business units in all over the world (Megginson \& Boutchkova, 2000). One primary objective of privatization is to increase productivity and to improve economic efficiency of the previous state-owned companies.

State-owned economy was preferred to non-state owned economy in the past but people started to understand that there were some serious concerns such as the emerge of bankruptcy, management system weakness and other concerns, which were increased in 1970s-1980s and the inefficiency was dominated on most governments' economic activities.

Corresponding author. Tel: +98-362-5374411 Mobile: $+98-9133168526$

E-mail: snouri@khuisf.ac.ir (S. Nouri Hoseinabadi)

C 2013 Growing Science Ltd. All rights reserved.

doi: $10.5267 /$ j.msl.2012.12.011 
As a result, many government agencies attempted to increase their performances through privatization techniques. In Iran, there have been some changes on rules and regulations, which have facilitated privatization of state-owned companies. The stock pricing of these companies was not of high quality in Tehran Stock Exchange (TSE). One primary concern is to learn more on how to price state-owned companies in TSE but there is one important question, which is how long an IPO pricing could last on TSE and how good it is in long-run. Is long-run buy and hold return of the stock of state-owned companies privatized in TSE different considerably with the long-run buy and hold return of the market during the definite period? Is type of industry effective on price difference of the initial offering and future trading of stock price?

In this study, it is attempted to investigate the validity degree of initial stock pricing of state companies admitted in TSE and for the first time their stock shares are distributed in the stock market. In the current study, first some important concepts of privatization is explained, then the review of literature and research methods and hypotheses and finally the results of hypothesis test are presented.

\section{Theoretical basics of the study}

Privatization is an important factor in economic reforms plans accepted by many governments at international level. Privatization can be defined as total or partial output of the state companies performed by the final control of the government (Alexakis et al., 2008). Control transfer in these levels is recognized as stock investment level, which is delegated to the majority of board of directors and finally it is passed to the management team. Thatcher's government in Britannia for the first time introduced privatization in the early 1980 and these plans were scheduled based on the communication with cautious investment plan of the community (Seldon \& Collings, 2000). It has been over two decades where developed and developing economies and countries have participated in various types of privatization plans. Today, privatization is considered as a useful tool at international level for governments to improve the operational efficiency of the companies or increasing the capital in private sector for the favor of the government budget ( Alexakis et al., 2008).

Privatization goals are similar in all countries in the world where they mostly concentrate on the benefits considered through rebalancing between the private and state sector and the aim is to increase economic efficiency power. There are many reasons for privatization but some of them are common and they are specifically considered to increase efficiencies of the firms. Some of the reasons of privatization include the increase of economic efficiency, reduction of lost financial load of state-owned companies, reduction of state debts, equipment of internal resources for development and fair assignment of ownership share in all over the country.

Privatization includes the transfer of public ownership rights to private sector and there are different kinds of delegations. The selected method in delegation depends on the objectives of privatization plans. According to Vuylsteke (1989), delegation method includes a direct sale to private sector for enterprise investors or public and total or partial. It also includes public offering of share in stock market and it determines the private sector with strategic investment or common investment with partners. In addition, it includes general tender such as stock sale to staffs and management team, privatization coupons, company dissolution to sell the assets.

The selection of the good method for privatization is defined by a series of factors. First, the main goal of the government of privatization plan is to increase the efficiency of owned companies, increase in income of selling state assets or business development. The other objective is to form the present organization in terms of state investment influencing the required steps for transferring ownership and facility of the process. For instance, a limited state company, which is trading stock in rather simple privatization trend, consists of offering extra securities offered by state investment via securities. In addition, financial condition of state investment, which is the experience of developed and developing countries and it can show that privatization potential is not limited only to the 
strength of state companies. Finally, some of state investment activities, the development of capital market and social and political factors influence privatization method. Initial stock offering in market happens when the companies sell their securities for the first time in capital market to provide the necessary capital to the public. They expect that this share will be common in the market and will be traded by the public. Most of the companies start their activities by absorbing retail investors. There is a famous term that financing of the company is private and it is evident that there is not dynamic market for these stocks. If a company finds that it needs more capital, it is possible to do financing through stock market. Then, the company can increase the trading of the stock and receive good price for its stock besides the required financing for continuing its activity .

During the past two past decades, going to stock market through initial public offering is based on a due diligence by management team, investors and scientific centers. However, this interest can be due to the importance of initial distribution of stock market in economic and employment growth. The real concentration is on opportunities of gaining considerable profit creating the initial stock distribution for most of the investors. The initial public offering is the process in which the business is owned by small number of people. The experience of the market in most countries in the world has shown that initial public offering (IPO)s are normally tremendous fluctuations in different years. However, in recent years, a great number of state companies by publishing stock entered the capital market and based on privatization policies in Iran, the question is whether IPOs admitted in TSE is valid in long-run or not.

The main idea in privatization is that competition space and underlying system on the market obliged the private enterprises to have the efficient performance to the public sector. Based on this idea, different definitions have been presented consists of various dimensions of privatization. According to Veljanovski (1987) "privatization is a tool to improve the performance of economic activities via increasing the role of market forces on the condition that at least $50 \%$ of the state stock is delegated to private sector". Veljanovski (1987) stated that privatization as doing economical activities by private sector or transferring the ownership of assets to the private sector. Kay and Thompson (1986) defined privatization as "The term privatization include various methods to achieve the relationship between the government and private sector including anti-nationality or selling the assets belonging to the government, elimination of rules or limiting regulations and introducing the competition in absolute state exclusions and outsourcing the goods and services financed by the government to the private sector". Privatization is an execution, financial and legal process performed by many governments in most of the countries in the world for reforms in economy and administrative system.

The term privatization is considered as the change in the balance between the government and market. Privatization can also be considered as a tool to increase efficiency either financially or socially. It appears that demand and supply mechanism and market in competition conditions caused the implementation of production factors, increasing the efficiency of the factors and more production of the products, services and reduction of prices. Indeed, privatization is a combination of innovative policies and in the simple state and privatization is ownership transfer. In this circumstances, the ownership and supervision are not the same and the determining factor is supervision (Company Information Exchange, 2006).

The governments experienced privatization in all over the world for different reasons. On one hand, international institutions such as World Bank, regional development banks and international monetary fund forced the developing countries for privatization of state enterprises and on the other hand, some local challenges such as correspondence with the market, job opportunities, increasing the income and efficiency increase for competition in global economy are some of the main reasons for privatization. In Iran, 
Some of the important reasons of privatization in Iran include the unduly rules in most fields, renovation of potential market, the lack of consistency of paying the wages in state-owned system and market competition.

Privatization causes entrepreneurship and increases the efficiency and value added and the total supply is increased and the response to the demand can be increased too. This makes the prices balanced and inflation is controlled and purchase power of the society is established that finally led into the increase of life level and social welfare. This is performed with the aim of increasing the efficiency of economic activities because theoretically, privatization is based on this thought that "Market environment is established when total competition is established". Private sector acts as economic efficiency is obtained. Via privatization and creating a competition environment, the producer is obliged to produce and sell its products and services with lower prices. The advantage of the private sector is to increase competition and to control rules and regulation. This is not possible in state-owned structure. Thus, privatization leads into the reduction of costs, growth and innovation and reduction of the price of goods.

Ibbotson (1975) is believed to be the first who investigated IPO pricing based on regression method where return variable was applied based on time and the type of security. The results of the study showed that the return of stock trade in secondary markets in the first year was positive, negative in three next years and positive in the fifth year. Ibbotson (1975) explained that the most considerable thing in IPO is that the selection of financing institutions and the validity of these institutions are effective on the new stock price of the company in the market. In summary, the more the validity of the financing institution, the more interest of the investors for purchasing more stocks.

Ritter (1991) in another study showed that the 3-year return of new entry stock in United States over the period 1975-1984 is mostly lower than the stock return of other companies during the definite period. In this study, for each new share, a similar company as a benchmark is considered in terms of industry and company size and the return of new stock is compared with the similar company return active in the market. The results of Ritter study showed that long-run return of new stocks was different from one year to another based on different industries.

Talebi (1995) used the reject or support model to study the relationship between current value price of future earning of the stock and the initial price of the trading of the privatized companies tested two methods using two methods. The first method calculated the return average rate of stock earning with the expected return rates $20,40,60 \%$ and the results were compared with the initial stock price in TSE. The results showed that the logical valuation facilities are limited on privatized unites.

Padgett and Chi (2005) performed a study on the reasons of low price of IPOs in short-run in China by studying 668 IPO companies over the period 1996-2000 in Shanghay and Shenzhen stock markets. They found that initial balanced average returns of IPO based on common trend of the market were $129.16,126.93,126.93$ and $124.95 \%$ in the first, fifth, tenth and twentieth trading days, respectively. The reason of low price of IPO was explained as high demand and sharing system and also lack of knowledge of a great number of individual investors. The estimations showed that information dissymmetry explained the low price of IPO in China. In terms of government behavior, the government by low price of the stock did not demonstrate the sign of the work quality to the market. However, it implemented the market opportunities for IPO scheduling to reach the best market feedback about these recommendations. In addition, government ownership had negative influences on the low prices. Because this is assumed that privatization is the favorite issue of the investors.

Ritter and Welch (2002) performed an investigation on different IPOs and their pricing on US firms over the period 1981-2001. They reported that these IPOs had valued about 488 billion $\$$ in total trading and at the end of the first day of the trading. Regarding the investors who purchased IPO in the first offering day and with the recent rate and hold it for 3 years, the return reached $22.6 \%$ during these 3 years, IPOs had low performance to the balanced value index to $23.4 \%$. 
Drobtez et al. (2003) studied stock pricing performance in initial stock offering by looking into different evidences of Swiss. They investigated the performance of a set of initial stock distribution in Swiss stock market over the period 1983-2000. The results of their study showed that the adjusted initial return average of the market was $34.97 \%$. Based on various parts of the market they explained that the adjusted initial return average in the main part of the market, from 1994 to 2000, was $11.32 \%$ and for new part of Swiss stock market, from 1999 to 2000, was 38.98\%. This difference was significant statistically and the results of the study showed that the lack of confidence hypothesis, informing hypothesis and market cyclicality hypothesis could justify the low price in Swiss stock market.

Mehrjo (2004) investigated stock pricing performance in IOPs of the companies in Tehran Stock Exchange (TSE) and short-run stock return of new entry companies of TSE. The results of the study showed that pricing of these companies in TSE was weak due to short-run return of stock sell and purchase of these companies was more than short-term return of the market during the similar period.

Salehi (2006) in another study investigated the validity of initial stock price of the companies admitted in TSE. Salehi investigated the validity or the lack of validity of the initial stock price. Indeed, this study attempted to investigate the accuracy of initial stock price of the companies admitted in TSE. In this study, a general degradation model of the value of future earning of the share was used to determine the current value of future earning of the stock. Finally, the price that stock holders give for purchasing the newly stock accepted in TSE was not reported equal to the earning of this stock in following years.

Bessler and Thies (2007) studied long-run performance of stock pricing in the initial stock offering in Germany. They studied the long-run performance of stock initial distribution in Germany stock market over the period 1995-1977. They reported that one important factor in determining the abnormal return was financing opportunities in the years after the initial stock distribution.

Ameri (2009) investigated the validity of pricing methods in IPOs in privatization companies and investigated whether stock pricing in the first offering day showed the inherent value of stock or not. They reported that the determined values via using the current value of future profits, nominal value, nominal value with inflation index and economical added-value had significant difference with the delegation prices of the companies.

\section{The proposed model}

This study is an empirical study in accounting research field based on real information of financial statements and other reports of the companies including most stocks whose shares are offered in TSE over the period 2001-2006 based on FA sampling technique. The scope of the study is the companies given to the private sector admitted in TSE. The privatization organization gave the required stock via tender, stock and negotiation to the above sectors. In this study, the delegations done by stock and securities stock market are considered. In other words, the study sample of this research includes companies delegated to private sector in TSE. The reason for selecting the delegated companies in TSE is to have an access to financial information of the companies. Due to the regulations and standards of TSE, the financial reports information of these companies is homogenous.

To estimate the models of the study, the companies did not meet the following conditions were considered as study sample and the companies that met the following conditions were excluded:

1- The privatization companies being delegated for the debts of the government to non-government public institutions.

2- The privatization companies being giving to the common people as justice stock. 
Thus, data collection was restricted to the companies with the above conditions leading into the selection of a 301 sample over the period 2001-2006.

For testing hypothesis, the difference between Beacon Hill Share Price (BHR) of the privatized companies is calculated during 36-month in TSE from long-run return during the similar period. To do this, a variable called buy-and-hold abnormal return (BHAR) is defined, which is equal to the difference between buy and hold return difference of the privatized companies with the long-run return of the market during 36-month. To test the hypothesis, this variable with numerical value of zero is compared by t-statistic. If the average of this difference is significantly different from zero, the main hypothesis is supported, otherwise there is no reason to reject null hypothesis in this test. Then, the effect of industry type is investigated on the difference between BHR differences of privatized companies in long-run with the market return during the similar period.

It can be said that all the required data of the study based on the list of new entry companies, their stock price at first and the stock return during 36-month, and the type of industry all are extracted of Pars Portfolio, TadbirPardaz, Sahra software privatization organization site. In addition, in some cases the company admittance statement is referred for more information. Finally, the information are analyzed by Eviews software version 6 and SPSS version 16.

\section{The hypotheses and data analysis}

The primary objective of this survey is to investigate the significance of the difference of BHR of the privatized companies during 36-month in TSE to the long-run return of the market during the similar period and the effect of industry type on the long-run performance of IPOs of privatized companies. Two hypotheses were formulated as follow:

Hypotheses:

1) "BHR of stock of the privatization companies is different in long term with BHR of the market"

2) "The type of industry is effective in BHR of the privatized companies during 36-month in TSE to the long-run return of the market during the similar period".

In this study, for testing different hypotheses, the combination of Drobetz et al. (2003) and Bessler Ties (2007) models was used. Before calculating BHR of each stock, it is required to calculate the new stock monthly return during 36-month of the start of activities of the company in stock market based on Eq. (1) as follows,

$R_{i, t}=\frac{C F_{i, t}+\left(P_{i, t}-P_{i, 0}\right)}{P_{0}}$

where

$\mathrm{R}_{\mathrm{i}, \mathrm{t}}$ is stock return $i$ during one month period $t$

$\mathrm{CF}_{\mathrm{i}, \mathrm{t}}$ : is cash flows of stock $i$ during 1 month $t$

$\mathrm{P}_{\mathrm{i}, t}$ : is stock price $i$ at the end of one month period $t$

P0: The balanced average of stock price $i$ in the first week after the initial offering in the stock.

For investment of one stock, BHR of stock $i$ for period $\mathrm{T}$ is calculated based on Eq. (2) as follows, 
$B H R_{i, T}=B H R_{i, T}=\left[\prod_{t=1}^{T}\left(1+R_{i, t}\right)\right]-1=\left[\left(1+R_{i, 1}\right)\left(1+R_{i, 2}\right) \ldots\left(1+R_{i, t}\right)\right]-1$,

Market return is calculated based on Eq. (4) as follows,

$R_{m, t}=\frac{P_{m, t}-P_{m, 0}}{P_{m, 0}}$

where

$\mathrm{R}_{\mathrm{m}, \mathrm{t}}$ : The return of general changes of the companies admitted in the stock at time $\mathrm{t}$

$\mathrm{P}_{\mathrm{m}, \mathrm{t}}:$ Stock price index at time $\mathrm{t}$

$\mathrm{P}_{\mathrm{m}, 0}$ : stock price index during the initial stock offering $\mathrm{i}$

Finally, to calculate BHAR, market return is subtracted of the new stock return as follows,

$$
\begin{aligned}
& \operatorname{BHAR}_{i, T}=\left(\prod_{t=1}^{T}\left(1+R_{i, t}\right)\right)-\left(\prod_{t=1}^{T}\left(1+R_{M, t}\right)\right), \\
& B H A R=\frac{1}{N} \sum_{i=1}^{N}\left[\left(\prod_{t=1}^{T}\left(1+R_{i, t}\right)\right)-\left(\prod_{t=1}^{T}\left(1+R_{M, t}\right)\right)\right] .
\end{aligned}
$$

To test the first hypothesis, the difference of privatized companies BHR during 36-month was calculated in TSE of long-run return of the market during the similar period. To do this, a variable called BHAR was defined equal to the difference between the BHR of privatized companies with long-run return of the market during 36-month. The statistical statement of first hypothesis is as follows:

$\begin{cases}H_{0}: & \mathrm{BHAR}=0 \\ H_{0}: & \mathrm{BHAR} \neq 0\end{cases}$

For first hypothesis test, this variable with zero numerical value was compared by t-statistics. If the average of this difference from zero was significantly different, the first hypothesis is supported otherwise there is no reason to reject the null hypothesis in this test. After testing the first hypothesis, the effect of industry type is investigated on the difference between BHR of the privatized companies in long-run with market return during the similar period. The reason of the selection of this factor and evaluation of its influence on the main variable is that most of the researchers stated some comments associated with the impact of industry type on pricing and long-run return of the new entry companies.

Based on the specific conditions of the companies in Iran market, it seems that high factor had maximum impact on pricing and long-run return of the new entry companies. In this study, to make an assessment on the impact of type of industry on dependent variable, price difference or long-run return of selling and purchasing the stock of the firms newly admitted in TSE, the common classification in TSE has been used. Due to the stratified nature of this variable, variance analysis method was implemented. According to this method, the effect of type of industry is tested under the following hypotheses,

$\begin{cases}H_{0}: & \gamma_{1}=\gamma_{2}=\cdots=\gamma_{17} \\ H_{1}: & \gamma_{1} \neq \gamma_{2} \neq \cdots \neq \gamma_{17}\end{cases}$ 
where $\gamma$ in the above statistical statement means the impact of type of industry, which is categorized into 17 classifications. In this case, if this impact is similar from one industry to another, the null hypothesis is supported in this test, otherwise in case of the different long-run return of the companies active in various industries, there is no reason to support null hypothesis. It is defined that industry factor is an effective variable on dependent variable of BHAR of the companies given to the market. In this study, for hypotheses test, inference test was applied. Inference statistics was consisting of the observed test statistics and significance level to support or reject the hypotheses. For various hypotheses test, significance level 5\% was applied to support or reject the hypotheses. To test the first hypothesis, BHAR variable with zero value is compared by t-statistics and Table 1 shows details of our findings,

\section{Table 1}

The results of the first hypothesis test

\begin{tabular}{ccccc}
\hline Main variable & $\begin{array}{c}\text { Degree of } \\
\text { freedom }\end{array}$ & $\begin{array}{c}\text { Significance } \\
\text { level }\end{array}$ & $\begin{array}{c}\text { Low boundary of } \\
\text { confidence distance }\end{array}$ & $\begin{array}{c}\text { High boundary of } \\
\text { confidence distance }\end{array}$ \\
\hline $\begin{array}{c}\text { Buy-and-Hold Abnormal } \\
\text { return (BAHR) }\end{array}$ & 300 & 0.007 & -0.0523 & -0.4921 \\
\hline
\end{tabular}

The results of this test show the rejection of $\mathrm{H}_{0}$ and supporting $\mathrm{H}_{1}$. This can be supported based on significance level 0.007 in the above table and this number is less than 0.05 alpha for statistical analysis. It can be said that with confidence interval $95 \%$, the difference of averages is in interval 0.0523 to 0.4921 and as both confidence distance boundaries are negative (-0.0523 and -0.4921$)$, long-run return of buy and hold stock of the firms given to the stock market after 36 months is less than long-run return of the market during the same period. This shows that in Iran stock, the market activity regarding the stock pricing of the companies is similar to the performance of the capital markets of other countries.

As mentioned earlier, the results of different studies on the performance and stock return of the companies given to the market in long-run in the market of other countries demonstrates the weak level of initial pricing of the stock of the companies given to the market. In addition, the results show that long-run return of stock sell and purchase of these companies is less than long-run return of the market in the same period. Based on what we have explained before, the results of the second hypothesis are shown by variance analysis model in Table 2 .

\section{Table 2}

The results of second hypothesis test- Type of industry

\begin{tabular}{ccccc} 
Determination coefficient & Significance level & F statistics & df & Test Variable \\
\hline 0.128 & 0.01 & 3.527 & 16 & Type of industry
\end{tabular}

As shown in the results of the Table 2, type of industry variable is effective on BHAR variable of the companies. This is due to the significance level of 0.01 that is less than alpha 0.05 selected for the test. The result of this test shows that there is significant difference between BHAR of the companies' active in various industries and the type of industry can be one of the effective factors on BHAR of the companies. The statistical results of two main hypotheses are demonstrated briefly in Table 3 .

\section{Table 3}

The general results of the research

\begin{tabular}{clcc}
\hline Hypothesis & \multicolumn{1}{c}{ Hypothesis explanation } & Type of test & Test result \\
\hline First hypothesis & $\begin{array}{l}\text { The difference of long-run BHR of the new entry companies } \\
\text { compared to long-run return of the market during the similar period }\end{array}$ & $\begin{array}{l}\text { t-test } \\
\text { heject null } \\
\text { hypothesis }\end{array}$ \\
Second hypothesis & The effect of the type of industry of new entry company on BHAR & $\begin{array}{l}\text { Variance } \\
\text { analysis }\end{array}$ & $\begin{array}{l}\text { Reject null } \\
\text { hypothesis }\end{array}$ \\
\hline
\end{tabular}




\section{Conclusion}

This study investigated the performance of Iran stock in long-run pricing of the stock of the newly admitted companies. We have investigated the impact of industry type on this performance. The results indicated that long-run return of new entry companies in the market considerable was less than long-run return of the market during the similar period. Based on the observed result, it can be said that Iran stock market in terms of long-term return was less than newly privatized companies to the similar market of capital markets in other countries in the world. The result of other researches in the stock of other countries also confirmed this issue in the markets. The results of this study are similar the result in the study of Bessler et al. (2007), in which the performance of the market was investigated over the period 1977-1995. The results of this test on second hypothesis showed significant difference between BHAR of the companies' active in various industries. In other words, industry type was one of the effective factors on BHAR of the companies. Allen and Falhaber (1989) stated that in specific industries, public offering costs were considerably less than its benefits and new stocks can be attractive as a company accepts low stock price. While the company can make the most of low initial offering in specific time and in long-run or short-run, its return is increased.

Based on the results of the study, the limitations and recommendations of the study are as follows:

\section{Limitations}

1) In this paper, the difference of long-run BHR of privatized firms newly entered to the market was calculated without considering the risk of the companies via calculation of the different value of the return of new firms compared with long-run BHR during the similar period. If the risk level is considered as effective variable for calculating long-run return of the new entry company, it is possible that the achieved return is different with the calculated values in this study.

2) In this study, it is assumed that after accepting the privatized companies newly admitted in the stock market, the main variables of the company effective in calculation of the inherent value of the stock don't change. If profitability of the companies (after entering the stock market) is affected by some factors as increase of sale price, new contracts and similar factors and this issue can change the results of the test.

3) This study was performed during 2001-2006. Thus, in generalizing the results to other time periods, we should be careful.

Based on the results of this study, we recommend the following points,

1) The investors should not only purchase the stock of new entry companies in short-run to use the benefits of it to invest in the stock of the similar companies in the market and increase their return in short term. Because based on the results of the studies, it is definite that pricing the stock of new entry companies to the market is at first under the real price and it causes that the short-run return of these companies is increased. By increase of short-run return, the long-run return of these companies is less than long-run return of other companies.

2) Based on the impact of industry type of the activity of the company on long-run return of privatized BHR, the investors must consider the type of industry during the purchase of the stock.

\section{References}

Allen, F., \& Faulhaber, G. (1989) Signaling by underpricing in the IPO market. Journal of Financial Economics, 23 (2), 303-323.

Alexakis, C.A., Kolomitsini, M.C., \& Xanthakis, M. (2008). Empirical tests on the stock price behavior of privatized enterprises in Greece. Journal of Money, Investment and Banking, 6, 5-16.

Ameri, L. (2009). Investigation on correctance of pricing inclusive private companies. AccountingMaster Thesis in Azad University. 
Bessler, W., \& Thies, S. (2007) The Long-run Performance of Initial Public Offerings in Germany. Managerial Finance, 33 (6), 420-441.

Company Information Exchange. (2006). Publication exchange, 55, 6-11\& 14-19

Drobetz, W., Kammermann, M., \& Wälchli, U. (2003). Performance of Initial Public Offerings: The Evidence for Switzerland. working paper, Basel University.

Ibbotson, R.G. (1975). Price performance of common stock new issues. Journal of Financial Economics, 2 (3), 235-272.

Kay, J., \& Thompson, D. (1986). Privatisation: A Policy in Search of a Rationale. The Economic Journal, 96, 18-32.

Megginson, W.L., \& Boutchkova, M.K. (2000). The Impact of Privatization on Capital Market Development and Individual Share Ownership. The Third FIBV Global Emerging Markets Conference \& Exhibition Federation of International Stock Exchanges, Istanbul, Turkey.

Mehrjo, H. (2004). The investigation on correctance of pricing in prior stock offering in Tehran stock. Accounting-Master Thesis in Shiraz University.

Padgett, C. \& Chi, J. (2005) Short-run underpricing and its characteristics in Chinese initial public offering (IPO) markets. Research in International Business and Finance, 19 (1), 71-93.

Ritter, R. (1991). The long-run Performance of Initial Public Offerings. Journal of Finance, 46, 3-27.

Ritter, J.R. \& Welch, I. (2002). A Review of IPO Activity, Pricing, and Allocations. Journal of Finance, American Finance Association, 57(4), pages 1795-1828.

Salehi, M. (2006) Investigation of correctance of initial price of adopted companies in Tehran stock.

Seldon, A., \& Collings, D. (2000). Britain Under Thatcher. Harlow: Pearson Education.

Talebi, G. (1995). Problems of pricing methods of stocks in inclusive companies. Financial research between Tehran \& Shahid Beheshti University, 7 \& 8.

Vuylsteke, C. (1989). Techniques of Privatization of State-Owned Enterprises. World Bank Technical Paper, 88.

Veljanovski, C. (1987) Selling the State: Privatization in Britain. London: Wedenfeld and Nicolson. 